\title{
Hollow-core precast and two-way solid slabs: Cost estimation and time duration comparison
}

\author{
Osamah Sarhan ${ }^{*}$, Mahdy Raslan ${ }^{1}$, Gazi Tallawi ${ }^{1}$ \\ ${ }^{1}$ Civil Engineering Department, Near East University, Nicosia, Mersin 10, Turkey
}

\section{A R T ICLE INFO}

\section{ARTICLE HISTORY:}

Received: 16 January 2020

Revised: 10 January 2021

Accepted: 21 January 2021

Published: 31 January 2021

\section{KEYWORDS:}

Precast, solid slab, hollow core, quantity surveying, scheduling

\begin{abstract}
A B S T R A C T
Time and cost are important factors affecting the successful completion of the construction building project. This study analyses and examines the cost and time comparison of precast and cast-in-situ slabs of a particular building. Taking into account that slab is one of the important structural members, this study will take the hollow core slab in particular which can define as precast prestressed concrete elements contain an empty void inside of it which mostly used for floor, roof slabs and wall panels. The results demonstrate that the precast slab construction time is extremely faster in comparison with the cast-in-situ slab as it took around 31 of working days and 43 days in total after considering the holidays while the precast slab took around 9 working days only and 13 days in total. The results also show that the cast-in-situ slab is inferior in both cost and time duration. As cast-in-situ cost is 3.76 times higher than the precast slab, and the time duration is 3.31 times longer.
\end{abstract}

\section{INTRODUCTION}

Nowadays, concrete is the most wildly used building materials over the world to the limit that it represents the cornerstone of our modern building civilization. Without concrete, our environment will not be able to maintain our modern lifestyle. Furthermore, our civilization will fall back dramatically to an era of underdevelopment. Concrete as a building material possess the required strength, durability, and a lot of additional features which is much superior to other materials, besides its cheap cost due to its basic component materials which include sand, gravel, and water that ranges between $15-30 \%$ of its initial mass. Concrete has a wide range of uses in construction, in buildings, roads, bridges, dams, retaining walls, etc. Moreover, it is a material that can be easily used and formed as required by pouring into reusable moulds. Concrete can be either be produced precast or cast-in-situ concrete. This study analyses and examines the cost and time comparison of precast and castin-situ slabs of a particular building. Taking into account that slab is the most important structural element; therefore, this study will take the hollow core slab in particular which can define as precast prestressed concrete elements contain an empty void inside of it which mostly used for floor, roof slabs and wall panels. The successful completion of the project within the minimum cost and estimated time duration is the main goal for all contractors to gain more revenue and reputation from the project.

\section{METHODOLOGY}

This study is a case study based on a selected building that was designed by a precast company in Saudi Arabia. The analysis was based on actual working drawings and bills of quantities of the completed project. The information for the research was obtained mainly from books, journals, personal interviews, and actual site measurements. The study consists of quantity surveying for the solid slabs of the building in addition to cost estimation for its components by taking into consideration the local pricing in Cyprus, and the building's slabs will be designed using ETABS software. The study will include each construction step and its time duration to make comparison schedules that show the differences and to identify the pros and cons of each slab 
type out of contracting company point of view. The research plan is illustrated in Fig. 1.

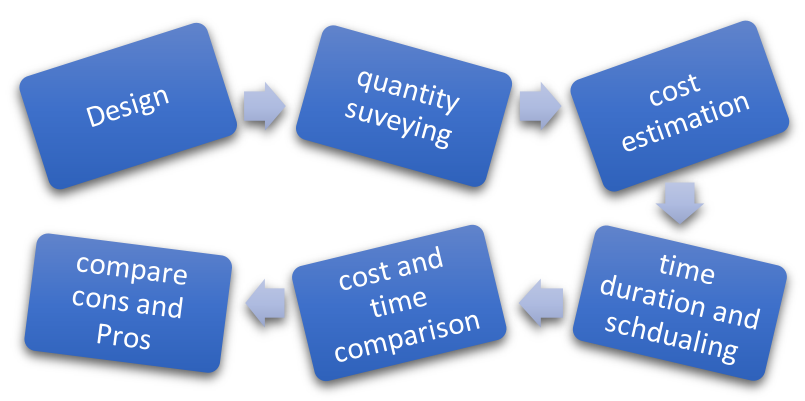

Fig. 1. Research plan

\section{CONCRETE CONSTRUCTION}

\subsection{Cast-in-place structure}

Cast-in-site concrete is the traditional and the most widely used type of concrete around the world due to its futures. This type of concrete can be either mixed on the site or the factory and transported to the site by using a special concrete truck. In-site concrete can be defined as the method of purring liquid concrete directly to the structural element's moulds at the construction site and curing it to gain its desired strength. Therefore, it requires highly skilled labourers and a lot of consideration and countermeasures to prevent some problems and defects that may arise and occurs during the process. Like the segregation problem that can cause the engineer to take the decision of breaking it and re-pouring concrete again, however, to avoid this kind of problem it must use vibratos and pouring concrete in the form of layers as well as it is imperative to pour concrete from a height of no more than one meter. In-site concrete is a long-processes that can take a lot of time, whereas it is known that concrete takes around 28 days to gain approximately its full strength. Therefore it can lengthen the overall project duration considerably. In addition to various tests to verify that the finished product meets the required designed result for strength. For example, the concrete slump test is used to measures the consistency and workability of the fresh concrete before it sets, and the cube test to check the strength of concrete and other tests that may be performed. Moreover, in-site concrete has a long history in humanity, to when it was first discovered. However, precast concrete can be considered a newly discovered product in comparison. Where according to Pepin (2019) the earliest recording of concrete structures was back to 6500 B.C. by the Nabataea in Syria and Jordan, while our modern concrete mixture was developed after 1793 and by 1824 Portland cement was invented by "Joseph Aspdin" also, he invented the reinforced concrete in 1849. After that, the concrete industry continued to improve over time.

\subsection{Precast structure}

Precast structures are a very high and advanced applied construction technology which can be defined as a type of construction elements made of concrete cast in a reusable mould according to the required shape, strength, and crosssection, and cured in the factory under a controlled condition, and therefore provides the highest quality. Finally, transported to the construction site and fixed into its place. The precast construction implementation process is easy, fast, and can save a lot of efforts. Therefore, in most developed countries, the use of that kind of structure is wildly relied on. Nowadays, this system has been widely used in constructing bridges, office buildings, residential buildings and hospitals which was preferred because it allows long spans and very light estimated dead load, thus floors give maximum structural performance with minimum weight and allow us to reduce the beams, columns and foundation section sizes to save money. The design process of precast structure usually performed by the precast company as an additional service as well as the precast pieces transport to the client's warehouse. Precast concrete can be used in many structural elements when constructing a building, such as foundation, columns, beams, and slabs as a combination between precast and in-situ concrete can be done. Using precast can shorten and cancel many regular steps during building construction processes like curing process, and many regular field tests of concrete. Precast consecution and construction system can vary according to the building type, span length, and loading condition. As the most effective construction element is the slab, our study will be concentrated on the comparison between hollow core precast and cast-in-situ solid slabs. Hollow core slabs can be defined as a precast prestressed concrete element mostly used for floor, roof slabs and wall panels, and the most widely used type of precast flooring system. Because of its highly efficient design and its flexibility in addition to its easy implementation and control in the site. Historically, The first documented modern use of architectural precast concrete was in the church of North Dame du Raincy by architects Auguste Perret, and Gustave Perret was built in 1923 in Le Raincy, France (Jester, 2014).

\section{COMPARISON BETWEEN SLAB TYPES}

\subsection{Prices comparison}

In-situ traditional two-way slab construction costs directly related to the size of the slab, and the cost estimation depends on many sub-variables, and additional procedures must be used during the construction. Construction costs can be divided into seven major activities starting with 
scaffolding and framework then steelworks, and finally concrete pouring. But the highest cost in this slab type is the labours costs. The prices of hollow core slab pieces that the companies offer may vary significantly depending on many conditions and variables like transportation, the size of the project, and some other design specifications. However, the negotiations and tenders play a major role in determining the prices where the final choice is up to the contractor. Usually, the precast company cover transportation, labours, erection, and stockyard expenses, whereas the company gain back its profit by selling the precast pieces where the total price determined according to the construction area. Furthermore, many additional usual expenses such as scaffolding, wood, curing, framework, and additional steel usage do not exist, which make this kind of slab is easier to deal with and faster to construct.

\subsection{Pros and cons of comparison}

In this section, we will list and compare the main advantages and disadvantages of precast and cast-in-situ slabs. Tables 1 and 2 compare and summarize the cons and pros of both hollow core and two-way solid slab. Where the superiority of precast technology can be seen clearly

Table 1. Precast pros and cons

\begin{tabular}{|l|l|}
\hline \multicolumn{1}{|c|}{ Pros } & \multicolumn{1}{c|}{ Cons } \\
\hline $\begin{array}{l}\text { High thermal and acoustic } \\
\text { insulation properties }\end{array}$ & $\begin{array}{l}\text { Limited skilled workers in } \\
\text { the field }\end{array}$ \\
\hline Reduced construction period & $\begin{array}{l}\text { Low available of technology } \\
\text { in many regions }\end{array}$ \\
\hline Sustainable, long service use & Difficulty in transportation \\
\hline $\begin{array}{l}\text { Deflection controlled through } \\
\text { the use of pre-camber }\end{array}$ & \\
\hline $\begin{array}{l}\text { Low self-weight due to } \\
\text { optimized section properties }\end{array}$ & \\
\hline Dimensional accuracy & \\
\hline $\begin{array}{l}\text { Reduction in formwork } \\
\text { requirements }\end{array}$ & \\
\hline $\begin{array}{l}\text { Minimal dependency on } \\
\text { weather conditions }\end{array}$ & \\
\hline Consistent products quality & \\
\hline $\begin{array}{l}\text { Significant reduction in waste } \\
\text { generation and safety risks }\end{array}$ & \\
\hline Reduced cost of construction. & \\
\hline $\begin{array}{l}\text { Outstanding quality of the } \\
\text { product }\end{array}$ & \\
\hline
\end{tabular}

Table 2. Cast-in-site pros and cons

\begin{tabular}{|l|l|}
\hline \multicolumn{1}{|c|}{ Pros } & \multicolumn{1}{c|}{ Cons } \\
\hline Cheap labours & Takes a long-time duration \\
\hline $\begin{array}{l}\text { Unnecessary costs can be } \\
\text { removed because of the huge } \\
\text { experience in this field }\end{array}$ & $\begin{array}{l}\text { Many problems and defects } \\
\text { may arise during and after } \\
\text { pouring concrete. }\end{array}$ \\
\hline $\begin{array}{l}\text { Easy to modify the } \\
\text { constructions project }\end{array}$ & $\begin{array}{l}\text { Bad conditions may affect the } \\
\text { strength of concrete }\end{array}$ \\
\hline $\begin{array}{l}\text { Building materials are } \\
\text { abundant in the market }\end{array}$ & $\begin{array}{l}\text { Frequent need for a } \\
\text { framework }\end{array}$ \\
\hline $\begin{array}{l}\text { Professional labours are not } \\
\text { required }\end{array}$ & Heavy dead load \\
\hline & It requires many field tests \\
\hline
\end{tabular}

\section{DESIGN}

\subsection{The precast hollow core design}

In this study the Precast hollow core slab final design obtained from a precast company with all is calculations and details, the number of precast pieces is listed below in Table 3 , and the designed plan is shown in Fig. 2.

Table 3. The Number of Precast hollow-core slabs according to the company design

\begin{tabular}{|l|c|}
\hline \multicolumn{1}{|c|}{ Thickness } & Number of pieces \\
\hline Design of floor HC-25 & 10 \\
\hline Design of WC HC-25 & 15 \\
\hline Design of floor HC-20 & 20 \\
\hline Design of floor HC-15 & 25 \\
\hline Sum & 70 \\
\hline
\end{tabular}


DOI: https://doi.org/10.47346/ijaesa.v2i1.22

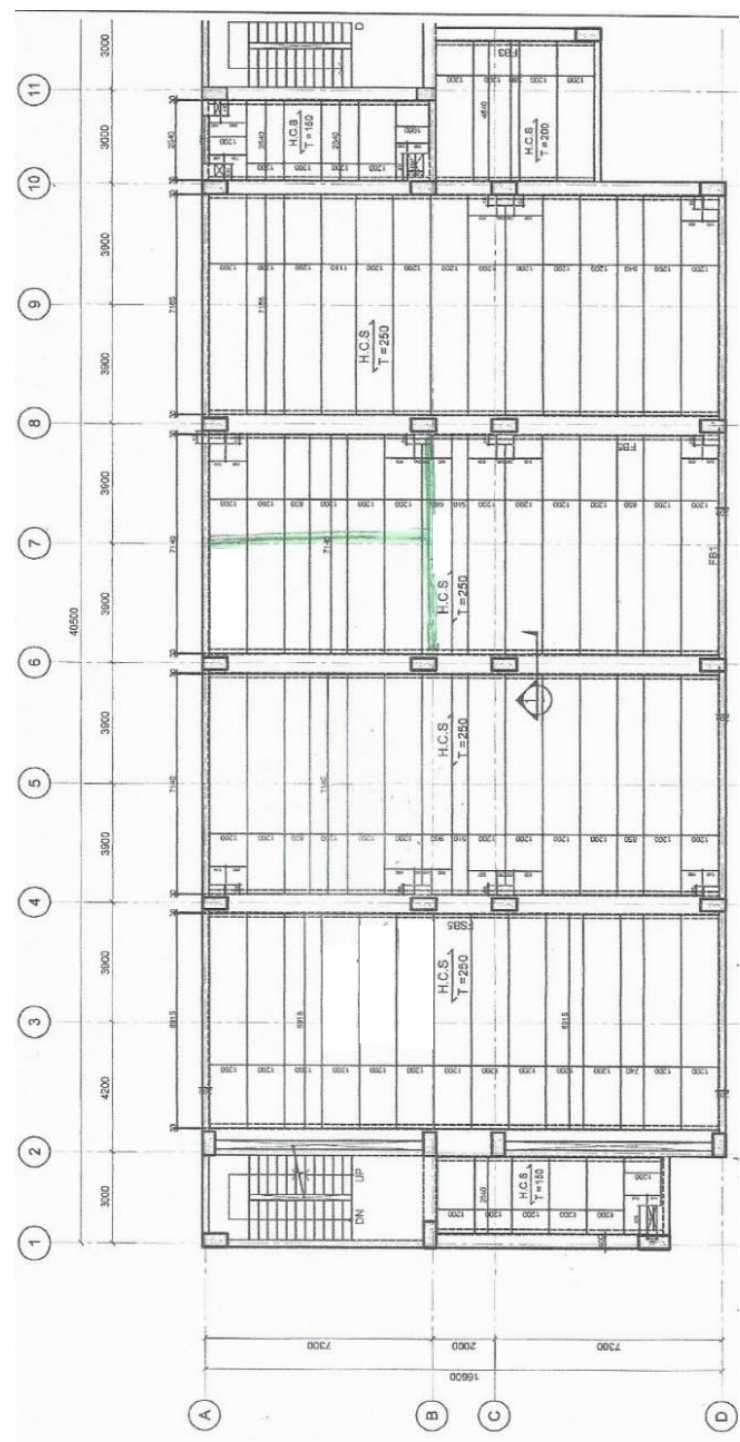

Fig. 2. Precast hollow core slab plan designed by the company

\subsection{Design performed applying ETABS}

The same building was designed using two-way solid slab applying ETABS 18.0.1 according to ACI-318-14 concrete design code considering the same load (live and super dead load) conditions that the company considered in the precast design. In our design, we used the same concrete and steel grade (C50, S275) as the precast company to reduce the variables and to get more reliable results. Fig. 3 shows the ETABS design.

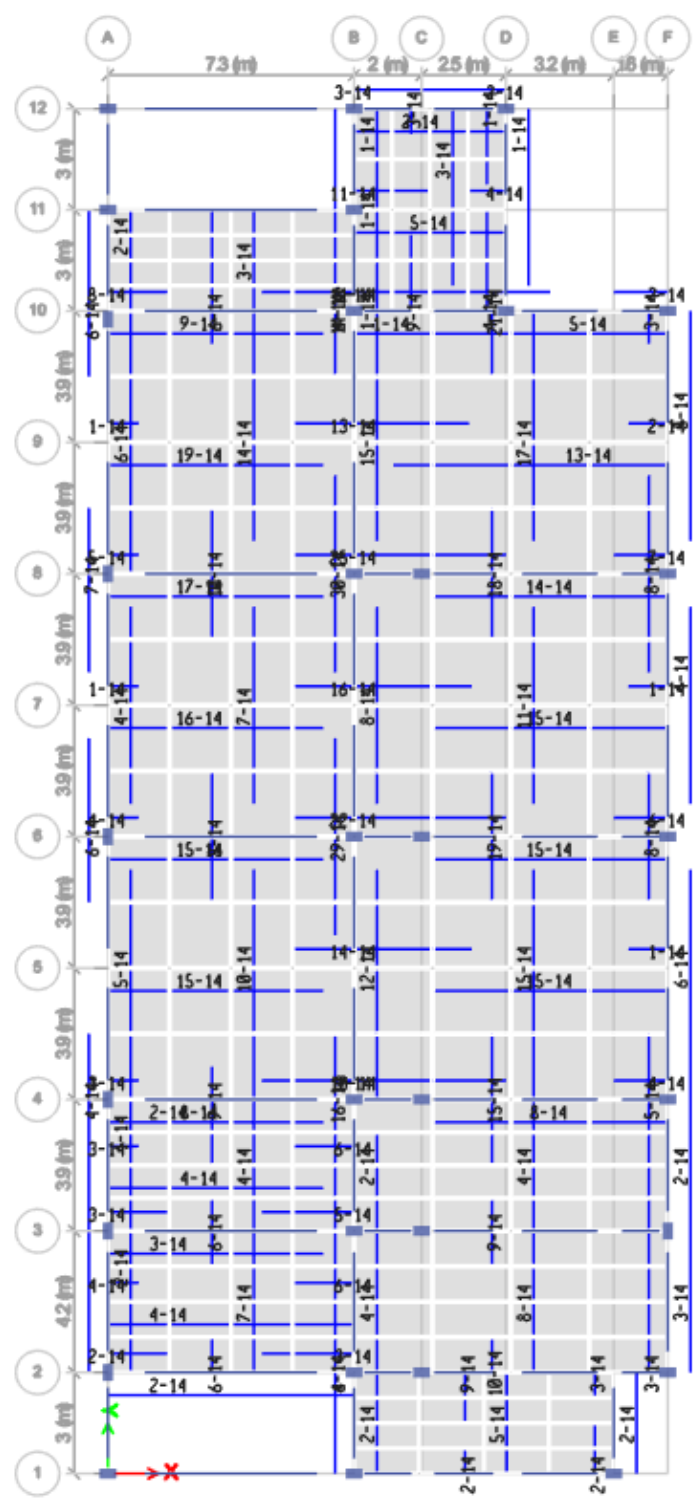

Fig. 3. ETABS two-way slab design

\section{SCHEDULING}

Both slab types in this study were planned in Primavera P6 Professional 18 software according to the list of activity shown in Table 4 and 5 to compare the duration between them. 
Table 3. Cast-in-site slab planning

\begin{tabular}{|c|l|c|c|c|}
\hline \multicolumn{2}{|c|}{ Activity } & Dependency & $\begin{array}{c}\text { Duration } \\
\text { (day) }\end{array}$ & $\begin{array}{c}\text { No. of } \\
\text { labours }\end{array}$ \\
\hline A & Scaffolding & - & 2 & 5 \\
\hline B & Framework & A & 3 & 10 \\
\cline { 1 - 2 } C & $\begin{array}{l}\text { Surveying } \\
\text { work }\end{array}$ & B & 2 \\
\hline D & Beams steel & B & 4 & \multirow{2}{*}{} \\
\cline { 1 - 2 } E & $\begin{array}{l}\text { Slab bottom } \\
\text { steel } \\
\text { installation }\end{array}$ & D, B & 6 & 10 \\
\cline { 1 - 2 } F & $\begin{array}{l}\text { Top steel } \\
\text { insulation }\end{array}$ & E, D, B & 6 & \\
\hline G & Cleaning & F, E & 1 & 1 \\
\hline H & Water spraying & G & 1 \\
\hline I & $\begin{array}{l}\text { Concrete } \\
\text { purring }\end{array}$ & H, G, E, F & 1 & 6 \\
\hline J & Curing & I & 7 & 1 \\
\hline \multicolumn{2}{|c|}{ Dismantle of frames after 28 days } \\
\hline
\end{tabular}

Table 4. Hollow-core slab planning

\begin{tabular}{|c|l|c|c|c|}
\hline \multicolumn{2}{|c|}{ Activity } & Dependency & $\begin{array}{c}\text { Duration } \\
\text { (day) }\end{array}$ & $\begin{array}{c}\text { No. of } \\
\text { labours }\end{array}$ \\
\hline A & Stockyard & - & 1 & \multirow{2}{*}{$\begin{array}{c}\text { Company } \\
\text { labours }\end{array}$} \\
\hline B & Delivery to site & A & 1 & 5 \\
\hline C & $\begin{array}{l}\text { Erection HC } \\
\text { slab pieces }\end{array}$ & B & 1 & 3 \\
\hline D & $\begin{array}{l}\text { Packing road } \\
\text { and grouting }\end{array}$ & C & 1 & 4 \\
\hline E & $\begin{array}{l}\text { Screed } \\
\text { concrete layer }\end{array}$ & D & & \\
\hline
\end{tabular}

After planning the cast-in-site two-way slab using Primavera software, as shown in Fig. 4 the estimated time duration is 31 days. When considering the holidays, the total duration of the project will increase to 43 days, where both Saturday and Sunday considered being a holiday.

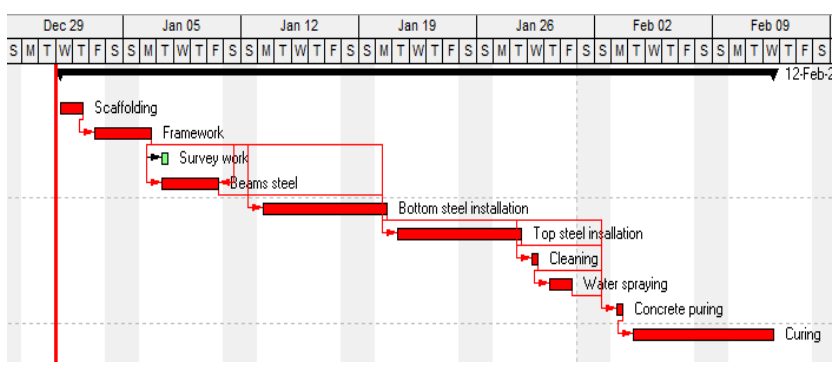

Fig. 4. Primavera planning of cast-in-situ slab

While the planning of the precast slab shown in Fig. 5 illustrates that the approximate time duration of the project is 9 days, and when considering the holiday times, the total duration of the project will be 13 days.

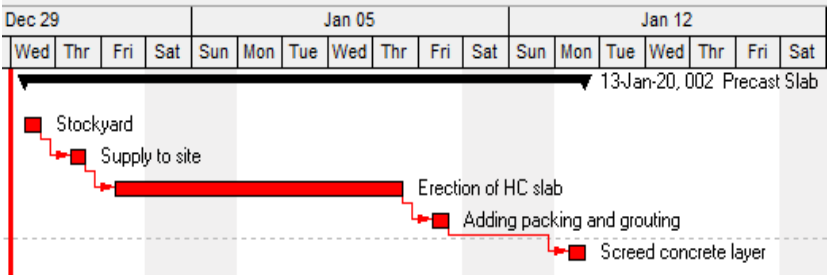

Fig. 5. Primavera planning of precast slab

\section{PRICES}

The hollow-core precast slab cost was obtained directly from the company documents, as all costs are listed in Table 6 . The prices are calculated according to the total surface area of the hollow core slab pieces. Also, the company take in consideration the labours and transportation costs while determining the unit cost of the slab piece because the company covers these costs. However, the crane cost is on the client.

Table 5. Precast slab prices

\begin{tabular}{|l|c|r|r|}
\hline \multicolumn{1}{|c|}{ Description } & $\begin{array}{c}\text { Approximate } \\
\text { quantity }\end{array}$ & \multicolumn{1}{c|}{$\begin{array}{c}\text { Unit } \\
\text { cost } \mathbf{\$})\end{array}$} & \multicolumn{1}{c|}{ Cost (\$) } \\
\hline $\begin{array}{l}\text { HCS } 150 \mathrm{~mm} \\
\text { thick span } 3 \mathrm{~m}\end{array}$ & $56\left(\mathrm{~m}^{2}\right)$ & 27.47 & $1,538.32$ \\
\hline $\begin{array}{l}\text { HCS } 200 \mathrm{~mm} \\
\text { thick span } 5.5 \mathrm{~m}\end{array}$ & $89\left(\mathrm{~m}^{2}\right)$ & 29.60 & $2,634.40$ \\
\hline $\begin{array}{l}\text { HCS } 250 \mathrm{~mm} \\
\text { thick span } 7.8 \mathrm{~m}\end{array}$ & $485\left(\mathrm{~m}^{2}\right)$ & 33.33 & $16,165.00$ \\
\hline Steel hanger & 1 piece & 133.33 & 133.33 \\
\hline Crane & 1 month & $5,867.00$ & $5,867.00$ \\
\hline \multicolumn{3}{|c|}{ Total } & $\mathbf{2 6 , 3 3 8 . 0 5}$ \\
\hline
\end{tabular}

On the other hand, the approximate costs for constructing the slab we designed using ETABS are listed in Table 6. The steel bars price is not fixed as it changes daily according to the steel market where the steel used in this study is S275. As for concrete, the prices can change significantly when using admixture to it, and sometimes using it is mandatory because of the long distance between the concrete factory and the construction project. In this case study, normal C50 concrete is used without adding admixtures to it.

Table 6. Cast-in-site slab costs

\begin{tabular}{|l|c|r|}
\hline \multicolumn{1}{|c|}{ Type } & Amount & Cost (\$) \\
\hline Steel bars & $9.354($ tons $)$ & $6,332.28$ \\
\hline Concrete & $126.014\left(\mathrm{~m}^{3}\right)$ & $9,241.03$ \\
\hline Skilled workers & $595\left(\mathrm{~m}^{2}\right)$ & $79,333.33$ \\
\hline Scaffolding & $85($ pieces $)$ & $4,080.00$ \\
\hline \multicolumn{2}{|c|}{ Total } & $\mathbf{9 8 , 9 8 6 . 6 4}$ \\
\hline
\end{tabular}




\section{CONCLUSIONS}

In this study, two different types of the slab were designed, analysed, and compared, which are cast-in-situ solid two-way slab, and hollow-core precast slab in terms of cost and completion time duration. The precast slab was predesigned by a construction company while the cast-insitu slab was designed using ETABS 18.0.1 software as the same load, and materials properties were applied. For each type of slab, the time duration was estimated according to the construction activities that it contains. Where the results showed that the precast slab construction time is extremely faster in comparison with the cast-in-situ slab as it took around 31 of working days and 43 days in total after considering the holidays while the precast slab took around 9 working days only and 13 days in total. Because the precast slab construction includes less activates than the cast-in-situ slab like framework, curing, steelwork, and concrete pouring. After estimating the cost of the two slab types, the difference in cost was extremely significant where the cast-in-situ slab costs approximately 98,987 dollars, considering the common pricing in Saudi Arabia. The construction of the cast-in-situ slab includes the steel and concrete cost, framework, skilled workers, and scaffolding. The skilled workers took the lion's share of the cost, which is 79,333 dollars. On the other hand, the precast slab costs around 26,338 dollars according to bill obtained from the company.

\section{CONFLICT OF INTEREST STATEMENT}

The authors declare that there is no conflict of interest.

\section{REFERENCES}

[1] ACI-318-14: Building Code Requirements for Structural Concrete and Commentary. (n.d.). Retrieved from

https://www.concrete.org/store/productdetail.aspx?Ite $\underline{\mathrm{mID}=31814 \& \text { Language }=\text { English }}$

[2] Amer, A., Arockiasamy, M., \& Shahawy, M. (1999). Load Distribution of Existing Solid Slab Bridges Based on Field Tests. Journal of Bridge Engineering, 4(3), 189-193.

https://doi.org/10.1061/(ASCE)10840702(1999)4:3(189)

[3] Aparna, A. (2017). International Journal of Research. Comparison of Prestressed Hollow Core Slab and Precast Concrete Beams- Hcb Slab System, 4(14), 2725-2731.

[4] Asamoah, R. O., Ankrah, J. S., Offei-Nyako, K., \& Tutu, E. O. (2016). Cost Analysis of Precast and Cast-inPlace Concrete Construction for Selected Public
Buildings in Ghana. Journal of Construction Engineering, 2016, 1-10. https://doi.org/10.1155/2016/8785129

[5] Chau, K. W., Anson, M., \& Zhang, J. P. (2004). FourDimensional Visualization of Construction Scheduling and Site Utilization. Journal of Construction Engineering and Management, 130(4), 598-606. https://doi.org/10.1061/(ASCE)07339364(2004)130:4(598)

[6] Elbeltagi, E., Hosny, O. A., Elhakeem, A., Abd-Elrazek, M. E., \& Abdullah, A. (2011). Selection of slab formwork system using fuzzy logic. Construction Management and Economics, 29(7), 659-670. https://doi.org/10.1080/01446193.2011.590144

[7] Gilbert, R. I., \& Mickleborough, N. C. (2002). Design of prestressed concrete. London: Spon Press.

[8] Hollowcore. (n.d.). Retrieved from http://www.gulfprecast.ae/hollowcore/

[9] Jester, T. C. (2014). Twentieth-century building materials: history and conservation. Los Angeles: Getty Conservation Institute.

[10] López-Mesa, B., Pitarch, Á., Tomás, A., \& Gallego, T. (2009). Comparison of environmental impacts of building structures with in situ cast floors and with precast concrete floors. Building and Environment, 44(4), 699-712. https://doi.org/10.1016/j.buildenv.2008.05.017

[11] Ng, W. M., Khor, E. L., Tiong, L. K., \& Lee, J. (1998). Simulation Modeling and Management of Large Basement Construction Project. Journal of Computing in Civil Engineering, 12(2), 101-110. https://doi.org/10.1061/(ASCE)08873801(1998)12:2(101)

[12] Nouban, F., \& Ghaboun, N (2017). the factors affecting the methods of construction projects scheduling: a state of the art and overview. Asian Journal of Natural \& Applied Sciences, 6(4), 114-222.

[13] Pepin, R. (2019). The History of Concrete. Retrieved from https://www.giatecscientific.com/education/thehistory-of-concrete/

[14] Orry Giovanni, “Analisa dan Perencanaan Pelat Beton Pracetak Sistem Hollow Core Slab (HCS) Untuk Pelat Satu Arah”, Tugas Akhir Universitas Sumatera Utara, 2008.

[15] Shapira, A. (1995). Formwork design for high elevated slab construction. Construction Management and Economics, 13(3), 243-252. https://doi.org/10.1080/01446199500000028

[16] Shen, L.-Y., Tam, V. W.-Y., \& Li, C.-Y. (2009). Benefit analysis on replacing in situ concreting with precast slabs for temporary construction works in pursuing sustainable construction practice. Resources, Conservation and Recycling, 53(3), 145-148. https://doi.org/10.1016/j.resconrec.2008.11.001

[17] Singh, S. (1991). Cost estimation of prestressed concrete beam and reinforced concrete slab 
construction. Construction Management and Economics, 9(2), 205-215.

https://doi.org/10.1080/01446199100000017

[18] Skjærvik, G. O. (2010). Process Control for Sustainable Precast Slab Production. Retrieved from https://www.concrete.org/publications/internationalco ncreteabstractsportal.aspx?m=details\&ID=51663949

[19] Trijeti., Atmawan, F.D., Aswanto, M. (2018). Time and Cost Comparison of Conventional and Alternative Plate Hollow Slab, Halfslab And Metal deck. International journal of scientific \& technology research volume, 7(6), 61-66. 